\title{
SIFAT MEKANIK VULKANISAT CAMPURAN KARET ALAM-KARET POLIBUTADIEN DENGAN BAHAN PENGISI ORGANOBENTONIT TEREKSPANSI
}

\author{
Mechanical Properties of Natural Rubber-Butadiene Rubber Blend Vulcanizates Filled \\ Expanded Organobentonite
}

\section{Irfan FATHURROHMAN dan Arief RAMADHAN}

Pusat Penelitian Karet, Jalan Salak No. 1, Bogor 16151

Email : irfan@puslitkaret.co.id

Diterima : 14 November 2014 / Direvisi : 4 Januari 2015 / Disetujui : 10 Maret 2015

\begin{abstract}
Natural rubber (NR) and polybutadiene rubber (BR) blend composites filled expanded organobentonite were produced by melting compounding in the open mill. Curing characteristics and mechanical properties of NR-BR blend vulcanizates filled expanded organobentonite (OBT) were compared with NR-BR blend vulcanizates (60:40) filled carbon black (CB) and silica (Si) with the equal loading of filler. Expanded organobentonite was produced from stearic acid intercalation into organobentonite so that obtained organobentonite with high basal spasing in order to rubber that easily intercalate into the gallery organobentonite. The results showed that maximum torque of $N R-B R$ blend compound filled OBT was smaller compared with the NR-BR compound filled $C B$ and $S i$. However, $S, t_{90}$ and $t_{s_{2}}$ were relatively similar. The mechanical properties of the NR - BR blend vulcanizates filled OBT were better than the NR-BR blend vulcanizates filled $C B$. Tensile strength, elongation at break, tear strength, and abrasion resistance of the NR - BR blend vulcanizates filled OBT were $12.57 \mathrm{MPa}$, $530 \%, 1.86 \mathrm{~N} / \mathrm{mm}^{2}$, dan $148.91 \mathrm{~mm}^{3} / 40 \mathrm{~m}$, respectively. Based on the results of mechanical properties, it could be concluded that the expanded organobentonite could be used as reinforcing filler in the NR-BR blend vulcanizates.
\end{abstract}

Keywords: Mechanical properties, NR-BR blend,expanded organobentonite

\section{Abstrak}

Komposit campuran karet alam (NR) dan karet polibutadien (BR) dengan bahan pengisi organobentonit terekspansi dibuat dengan cara pelelehan kompon di dalam open mill. Karakteristik pematangan dan sifat mekanik vulkanisat campuran NR-BR dengan bahan pengisi organobentonit terekspansi (OBT) dibandingkan dengan vulkanisat campuran NR-BR (60:40) dengan bahan pengisi carbon black (CB) dan silika (Si) dalam jumlah yang sama. Organobentonit terekspansi dihasilkan dari interkalasi asam stearat ke dalam organobentonit sehingga didapatkan organobentonit dengan basal spasi yang cukup besar agar karet mudah masuk ke dalam galeri organobentonit. Hasil menunjukkan bahwa torsi maksimum dari kompon campuran NR-BR dengan bahan pengisi OBT lebih kecil bila dibandingkan dengan kompon campuran NR-BR dengan bahan pengisi CB dan $\mathrm{Si}$. Namun, $\mathrm{S}, \mathrm{t}_{90}$ dan $\mathrm{ts}_{2}$ relatif sama. Sifat mekanik dari vulkanisat campuran NR-BR dengan bahan pengisi OBT lebih baik dibandingkan dengan vulkanisat campuran NR-BR dengan bahan pengisi CB. Kuat tarik, perpanjangan putus, kekuatan sobek, dan ketahanan kikis dari vulkanisat campuran NR-BR dengan bahan pengisi OBT masing-masing sebesar 12,57 $\mathrm{MPa}, 530 \%, \quad 1,86 \mathrm{~N} / \mathrm{mm}^{2}$, dan 148,91 $\mathrm{mm}^{3} / 40 \mathrm{~m}$. Berdasarkan hasil sifat mekanik, maka dapat disimpulkan bahwa organobentonit terekspansi dapat digunakan sebagai bahan pengisi yang 
bersifat menguatkan pada vulkanisat campuran NR-BR.

Kata kunci: Sifat mekanik, campuran NRB R, organobentonit terekspansi

\section{PENDAHULUAN}

Dalam pembuatan barang jadi karet, bahan pengisi digunakan sebagai bahan yang dapat meningkatkan sifat mekanik dan menurunkan harga kompon. Bahan pengisi yang biasa digunakan dapat bersifat menguatkan atau tidak menguatkan. Bahan pengisi yang bersifat menguatkan adalah carbon black yang berasal dari pembakaran minyak bumi. Bahan pengisi lain yang bersifat menguatkan tetapi tidak berasal dari minyak bumi adalah silika. Carbon black dan silika dapat menguatkan karena memiliki ukuran partikel nano dan biasanya dapat menguatkan komposit tetapi harganya lebih mahal dibandingkan dengan bahan pengisi lain (Carli et al., 2011). Selain itu pemakaian kedua bahan tersebut relatif banyak, sering kali melebihi 30 phr (Das et al., 2008).

Saat ini penggunaan lempung sebagai bahan pengisi karet yang bersifat menguatkan sudah banyak dipelajari oleh peneliti, di mulai dari keberhasilan para peneliti Toyota membuat nanokomposit nilon dengan bahan pengisi organoclay (Alexandre dan Dubois, 2000). Nanokomposit berbasis karet dengan bahan pengisi organoclay juga telah berhasil dibuat, diantaranya menggunakan karet NR (Lopez-Manchado et al., 2003), BR (Wan et al., 2008), SBR (Sadhu dan Bhowmick, 2004), CR (Das et al., 2008), dan IIR (Yong-Lai et al., 2006).

Peningkatan sifat mekanik, ketahanan terhadap suhu, rheologi, tahan bakar, dan permeabilitas dari nanokomposit karet dengan menggunakan organoclay disebabkan karena eksfoliasi dan interkalasi organoclay menghasilkan struktur platelet yang terdispersi dengan merata di dalam matriks karet (Shan et al., 2011), sehingga komposit tersebut dapat digunakan untuk berbagai aplikasi seperti pada industri otomotif, ban, konstruksi dan lain sebagainya.

Pencampuran antara karet alam dan karet sintetis sudah umum dilakukan di industri barang jadi karet, misalnya industri ban untuk bagian telapak biasanya menggunakan campuran karet alam, karet stirenebutadien (SBR) dan karet polibutadien (BR). Pencampuran ini dimaksudkan untuk memperbaiki sifat dari masingmasing karet, misal karet alam memiliki sifat mekanik dan dinamik yang baik, tetapi sifat ketahanan kikis dari karet alam kurang baik. Karet BR memiliki ketahanan kikis yang sangat baik (Datta, 2004). Pencampuran NR-BR diharapkan dapat menghasilkan vulkanisat karet yang memiliki ketahanan kikis yang lebih baik.

Pembuatan nanokomposit dengan bahan pengisi organoclay menggunakan pencampuran karet alam dan karet sintetis belum banyak diteliti. Shan et al (2010) membuat nanokomposit NR/SBR/organoclay. Penggunaan organoclay sebanyak $3 \mathrm{phr}$ ke dalam campuran NR/SBR dapat memperbaiki kuat tarik dan ketahanan sobek sebesar 92,8\% dan 63,4\%. Pada penelitian ini, organobentonit terekspansi digunakan sebagai bahan pengisi pada campuran karet NR dan BR bertujuan untuk membandingkan karakteristik pematangan dan sifat mekanik dari campuran NR-BR dengan bahan pengisi yang berbeda, yaitu organobentonit terekspansi, carbon black dan silika. 


\section{BAHAN DAN METODE}

Penelitian dilaksanakan di Pusat Penelitian Karet, Bogor pada periode bulan Mei - Juli 2013. Bahan yang digunakan pada penelitian ini adalah bentonit alam yang berasal dari Bogor. Sebelum digunakan sebagai bahan pengisi, bentonit alam dimodifikasi dengan menggunakan natrium karbonat $\left(\mathrm{Na}_{2} \mathrm{CO}_{3}\right) \quad 15 \%$ dengan grade teknis dan garam ammonium kuarterner Dihydrogenated Tallowoylethyl Hydroxyethylmonium Methosulfate yang diproduksi oleh KAO dengan merek dagang Tetranyl. Derajat keasaman diatur dengan menggunakan asam klorida (HCl) 1 M. Pembuatan nanokomposit dilakukan dengan metoda melt compounding dengan menggunakan campuran karet alam (NR) SIR 20 yang didapat dari PTPN VIII dan Polybutadiene Rubber (BR) yang disuplai oleh Lanxess. Bahan pengisi yang digunakan pada penelitian ini adalah carbon black 660 dan silika. Bahan kimia lain seperti pada Tabel 1 digunakan dengan grade teknis .

Tabel 1. Formulasi kompon NR-BR

Table 1. Formulation of NR-BR compounds

\begin{tabular}{|c|c|c|c|}
\hline $\begin{array}{l}\text { Bahan } \\
\text { Materials }\end{array}$ & $\begin{array}{c}\text { Organobentonit } \\
\text { terekopksidasi } \\
\text { Expended } \\
\text { organobentonite } \\
\text { (OBT) }\end{array}$ & $\begin{array}{l}\text { Arang hitam } \\
\text { Carbon black } \\
\text { (CB) }\end{array}$ & $\begin{array}{l}\text { Silika } \\
\text { Silica } \\
\text { (Si) }\end{array}$ \\
\hline Karet alam (Natural Rubber) & 60 & 60 & 60 \\
\hline Polybutadiene Rubber (BR) & 40 & 40 & 40 \\
\hline Carbon Black 660 & - & 10 & - \\
\hline OBT & 12 & - & - \\
\hline $\mathrm{Si}$ & & - & 10 \\
\hline Polyethylene Glicol (PEG) & 2 & - & 2 \\
\hline Silane coupling agent & 1 & - & 1 \\
\hline Minarex Oil & 6 & 6 & 6 \\
\hline $\mathrm{ZnO}$ (Zinc Oxide) & 5 & 5 & 5 \\
\hline Asam Stearat (Stearic Acid) & - & 2 & 2 \\
\hline High Stirene Resin & 2 & 2 & 2 \\
\hline Wax & 1 & 1 & 1 \\
\hline $\begin{array}{c}\text { IPPD (N'Isopropyl }-N^{\prime} \text { Phenyl }-P \\
\text { - Phenylene Diamine) } \\
\text { TMQ }(2,2,4-\text { Trimethyl }-1,2-\end{array}$ & 1,5 & 1,5 & 1,5 \\
\hline $\begin{array}{l}\text { dihydroquinoline) } \\
\text { MBTS (2'- Dibenzothrazole }\end{array}$ & 1 & 1 & 1 \\
\hline Disulfide) & 1 & 1 & 1 \\
\hline DPG (Diphenyl Guanidine) & 1 & 1 & 1 \\
\hline Belerang (Sulphur) & 2,24 & 2,24 & 2,24 \\
\hline
\end{tabular}

Pembuatan dan Karakterisasi Organobentonit Terekspansi

Organobentonit (OB) dibuat dengan menggunakan proses pertukaran kation di dalam reaktor mini yang dilengkapi dengan pengaduk dan alat pengendali suhu. Bentonit sebanyak 250 gram didispersikan dengan 7 liter akuades dengan cara diaduk pada $150 \mathrm{rpm}$ pada suhu $80^{\circ} \mathrm{C}$ selama 1 jam. Natrium karbonat sebanyak $15 \%$ b/b ditambahkan ke dalam dispersi bentonit dan diaduk kembali pada suhu dan kecepatan putaran yang sama selama 4 jam. $\mathrm{pH}$ larutan diatur sekitar 5 dengan menambahkan $\mathrm{HCl} 1 \mathrm{M}$. Garam ammonium kuarterner ditambahkan dengan dosis 4 Kapasitas Tukar Kation 
(KTK) ke dalam dispersi bentonit selama 2 jam. Organobentonit yang terbentuk disaring dan dicuci menggunakan air panas untuk menghilangkan ion klorida yang terdapat di dalam larutan. Ion klorida di cek dengan meneteskan larutan perak nitrat $0,5 \% \mathrm{~b} / \mathrm{v}$ hingga tidak terbentuk endapan putih. Organobentonit dikeringkan pada suhu $110^{\circ} \mathrm{C}$, kemudian digerus menggunakan mortar hingga berukuran 200 mesh. Organobentonit diekspansi dengan menggunakan asam stearat dengan tujuan untuk meningkatkan basal spasi dari organobentonit sehingga memudahkan karet untuk interkalasi ke dalam galeri bentonit. Organobentonit dicampur dengan asam stearat dengan perbandingan berat 10:2 menggunakan mortar selama 30 menit. Campuran tersebut dipanaskan di dalam oven selama 1 jam pada suhu $100^{\circ} \mathrm{C}$ kemudian didinginkan, selanjutnya digerus menggunakan mortar sampai berukuran 200 mesh. Campuran yang didapat dinamakan organobentonit terekspansi (OBT).

Karakterisasi organobentonit dilakukan untuk mengetahui $\mathrm{keberhasilan} \mathrm{pembuatan}$ organobentonit $(\mathrm{OB})$ dan organobentonit terekspansi ( O B T) dengan menggunakan difraksi sinar-X (XRD) dan Attenuated Total Reflectance Infra Red (ATR-IR). Pada penelitian ini menggunakan Difraktometer sinar-X (CuK) pada tegangan $40 \mathrm{kV}$ dan arus 30 $\mathrm{mA}$. Data XRD ditinjau pada sudut $2 \theta$ dari $2^{\circ}-10^{\circ}$ dengan kecepatan pembacaan $1^{\circ} /$ menit. Perhitungan nilai basal spasi menggunakan hukum Bragg's, yaitu $\lambda=2 \mathrm{~d} \sin \theta$. Spektroskopi infra merah ATR-IR digunakan untuk mengetahui interaksi garam ammonium kuarterner dan asam stearat dengan bentonit. Spektrum ATR-IR diukur pada rentang bilangan gelombang 4000 sampai $500 \mathrm{~cm}^{-1}$ dengan resolusi $4 \mathrm{~cm}^{-1}$.

\section{Pembuatan Kompon dan Vulkanisasi Campuran NR-BR}

Kompon campuran NR-BR dibuat dengan menggunakan open mill dengan perbandingan kecepatan 1:1,4 dan suhu gilingan dipertahankan pada suhu $65 \pm$ $50^{\circ} \mathrm{C}$. Formulasi kompon NR-BR dengan bahan pengisi yang berbeda disajikan pada Tabel 1. Kompon NR-BR yang telah digiling dikondisikan selama minimal 16 jam. Karakterisasi pematangan kompon N R-B R ditentukan dengan menggunakan rheometer (MDR 2000) pada suhu $150^{\circ} \mathrm{C}$ sesuai dengan ISO 6502. Kompon NR-BR kemudian divulkanisasi/dicetak dengan menggunakan alat tekan hidrolik pada suhu $150^{\circ} \mathrm{C}$ dan tekanan $100 \mathrm{~kg} / \mathrm{cm}^{2}$ dengan waktu vulkanisasi yang didapat dari hasil pengukuran dengan menggunakan rheometer. Ketebalan vulkanisat NR-BR adalah $2 \pm 0,2 \mathrm{~mm}$.

\section{Pengujian Sifat Mekanik Vulkanisat Campuran NR-BR}

Sifat mekanik vulkanisat campuran NR-BR ditentukan sesuai dengan standar metode uji ISO yang terdiri dari: uji kuat tarik dan perpanjangan putus, kekuatan sobek, kekerasan, perpanjangan tetap, kalor timbul, dan ketahanan kikis. Kuat tarik, modulus pada perpanjangan $100 \%$ dan $300 \%$ serta perpanjangan putus vulkanisat campuran NR-BR ditentukan sesuai dengan ISO 37 menggunakan dumbbell tipe 2. Kekuatan sobek vulkanisat campuran NR/BR menggunakan contoh uji berbentuk delft sesuai dengan ISO 34(2). Pengujian kekerasan vulkanisat campuran NR-BR sesuai dengan metode uji ISO 7619 menggunakan Shore A. Uji kalor timbul dilakukan sesuai dengan ISO 4666, pengujian dilakukan di suhu $50^{\circ} \mathrm{C}$ menggunakan contoh uji berbentuk silinder dengan diameter $20 \mathrm{~mm}$ dan 
tebal 25 mm. Pengujian ketahanan kikis dilakukan dengan menggunakan DIN abrader sesuai dengan metode uji ISO 4649. Contoh uji berbentuk silinder berdiameter $16 \mathrm{~mm}$ dengan tinggi minimum $6 \mathrm{~mm}$.

\section{HASIL DAN PEMBAHASAN}

Organobentonit (OB) dibuat dari bentonit yang memiliki puncak difraksi dengan basal spasi sebesar 1,30 nm seperti yang terlihat pada Gambar 1 . Basal spasi dihitung dari hukum Bragg, yaitu: $\lambda=2 \mathrm{~d} \sin \theta$. Setelah dilakukan reaksi pertukaran kation dengan menggunakan garam ammonium kuarterner, puncak difraksi dari bentonit bergeser dan peningkatan basal spasi menjadi $1,99 \mathrm{~nm}$. Hal ini menunjukkan bahwa telah terjadi pertukaran kation antara kation ammonium dengan kation-kation yang terdapat di dalam galeri bentonit. Menurut Le Puart et al (2002), organobentonit dengan basal spasi 1,99 $\mathrm{nm}$ menunjukkan bahwa ion-ion ammonium yang terdapat di dalam galeri bentonit berbentuk lapisan parafin. Selain itu pada pola difraksi OB terlihat adanya puncak difraksi dengan basal spasi 1,30 $\mathrm{nm}$. Hal ini menunjukkan bahwa pada OB tersebut masih terdapat bentonit yang tidak mengalami pertukaran kation dengan kation ammonium yang terdapat pada garam ammonium kuarterner Dihydrogenated Tallowoylethyl Hydroxyethylmonium Methosulfate.

Peningkatan basal spasi dari organoclay dapat meningkatkan interkalasi/eksfoliasi organoclay di dalam matriks karet sehingga memperbaiki sifat mekanik dari vulkanisat karet (Ma et al., 2008). Peningkatan basal spasi dapat dilakukan dengan menginterkalasi asam stearat ke dalam galeri organobentonit, menghasilkan OBT seperti yang disajikan pada Gambar 1 . Pada pola difraksi OBT, terdapat tiga puncak difraksi, yaitu dengan basal spasi 3,83 nm, 2,01 nm dan mendekati 1,30 nm. Puncak difraksi OB dengan basal spasi $1,99 \mathrm{~nm}$ bergeser, menghasilkan basal spasi 3,83 nm. Peningkatan basal spasi ini diharapkan dapat memudahkan karet masuk ke dalam galeri organobentonit, sehingga menghasilkan struktur interkalasi atau eksfoliasi. Puncak difraksi dengan basal spasi 2,01 nm merupakan puncak difraksi dari asam stearat yang mengalami rekristalisasi setelah proses pendinginan (Ma, 2007). Puncak difraksi dengan basal spasi 1,30 $\mathrm{nm}$ merupakan puncak difraksi dari bentonit yang tidak diinterkalasi oleh garam ammonium kuarterner dan asam stearat.

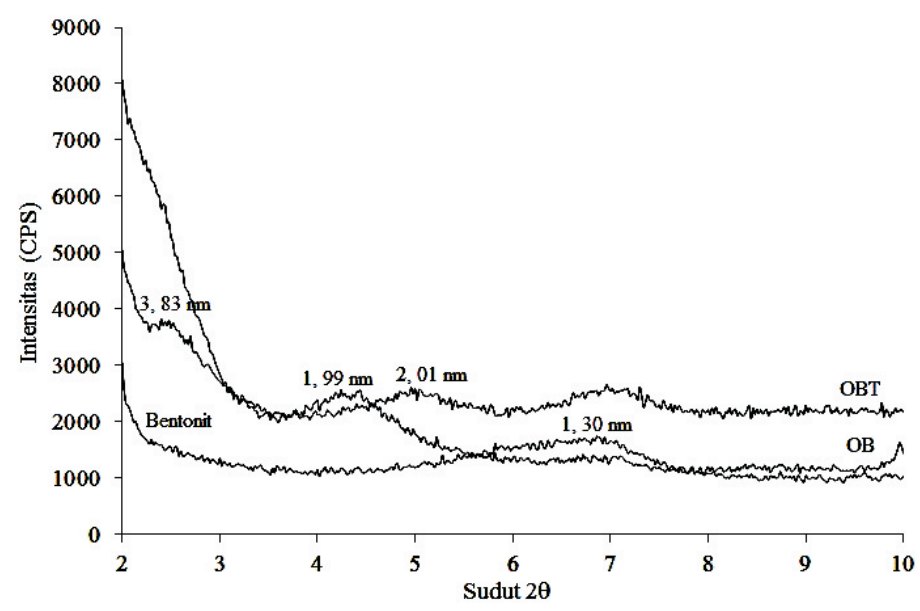

Gambar 1. Pola difraksi sinar-X bentonit, OB, dan OBT Figure 1. X-ray diffraction patterns of bentonite, $O B$, and $O B T$ 
Spektrum ATR-IR bentonit, organobentonit dan organobentonit terekspansi disajikan pada Gambar 2. Spektrum ATR-IR dari bentonit memperlihatkan adanya vibrasi ulur O$\mathrm{H}$ dalam $\mathrm{H}_{2} \mathrm{O}\left(3627,65 \mathrm{~cm}^{-1}\right)$, vibrasi tekuk $\mathrm{H}-\mathrm{O}-\mathrm{H}$ dalam $\mathrm{H}_{2} \mathrm{O}\left(1635,07 \mathrm{~cm}^{-1}\right)$, dan vibrasi ulur Si-O $\left(1008,18 \mathrm{~cm}^{-1}\right)$. Sedangkan spektrum ATR-IR dari organobentonit memperlihatkan adanya empat pita serapan baru, yaitu pada bilangan gelombang 2916,82 $\mathrm{cm}^{-1}$, $2849,58 \mathrm{~cm}^{-1}, 1732,22 \mathrm{~cm}^{-1}$, dan 1466,67 $\mathrm{cm}^{-1}$. Keempat pita serapan tersebut adalah pita serapan khas yang ada pada surfaktan ammonium kuarterner Tetranyl, yaitu pita serapan vibrasi uluran antisimetri $\mathrm{CH}_{2}$ pada bilangan gelombang 2916,82 $\mathrm{cm}^{-1}$ dan 2849,58 $\mathrm{cm}^{-1}$, gugus ester pada bilangan gelombang $1732,22 \mathrm{~cm}^{-1}$ dan vibrasi gunting $\mathrm{CH}_{2}$ pada bilangan gelombang $1466,67 \mathrm{~cm}^{-1}$ (Ramadhan et al., 2014). Hal ini menunjukkan bahwa kation- kation ammonium telah bertukar dengan kation-kation yang terdapat di dalam galeri dari organoclay.

Pada spektrum ATR-IR OBT terlihat munculnya puncak khas dari asam karboksilat pada bilangan gelombang $1698,98 \mathrm{~cm}^{-1}$ dan tidak terlihatnya puncak ester $\left(1732,22 \mathrm{~cm}^{-1}\right)$ pada spektrum OB, hal ini menunjukkan bahwa asam stearat pada saat mengalami pelelehan masuk ke dalam galeri OB dan mengalami rekristalisasi kembali di dalam galeri OB, namun tidak terjadi reaksi esterifikasi seperti hasil penelitian yang dilakukan oleh Ma et al (2008). Hal ini dimungkinkan karena grup hidroksi yang terdapat di dalam lapisan bentonit telah bereaksi dengan Tetranyl menghasilkan ester, sehingga pada spektrum OB muncul pita khas dari grup ester pada bilangan gelombang $1732,22 \mathrm{~cm}^{-1}$.

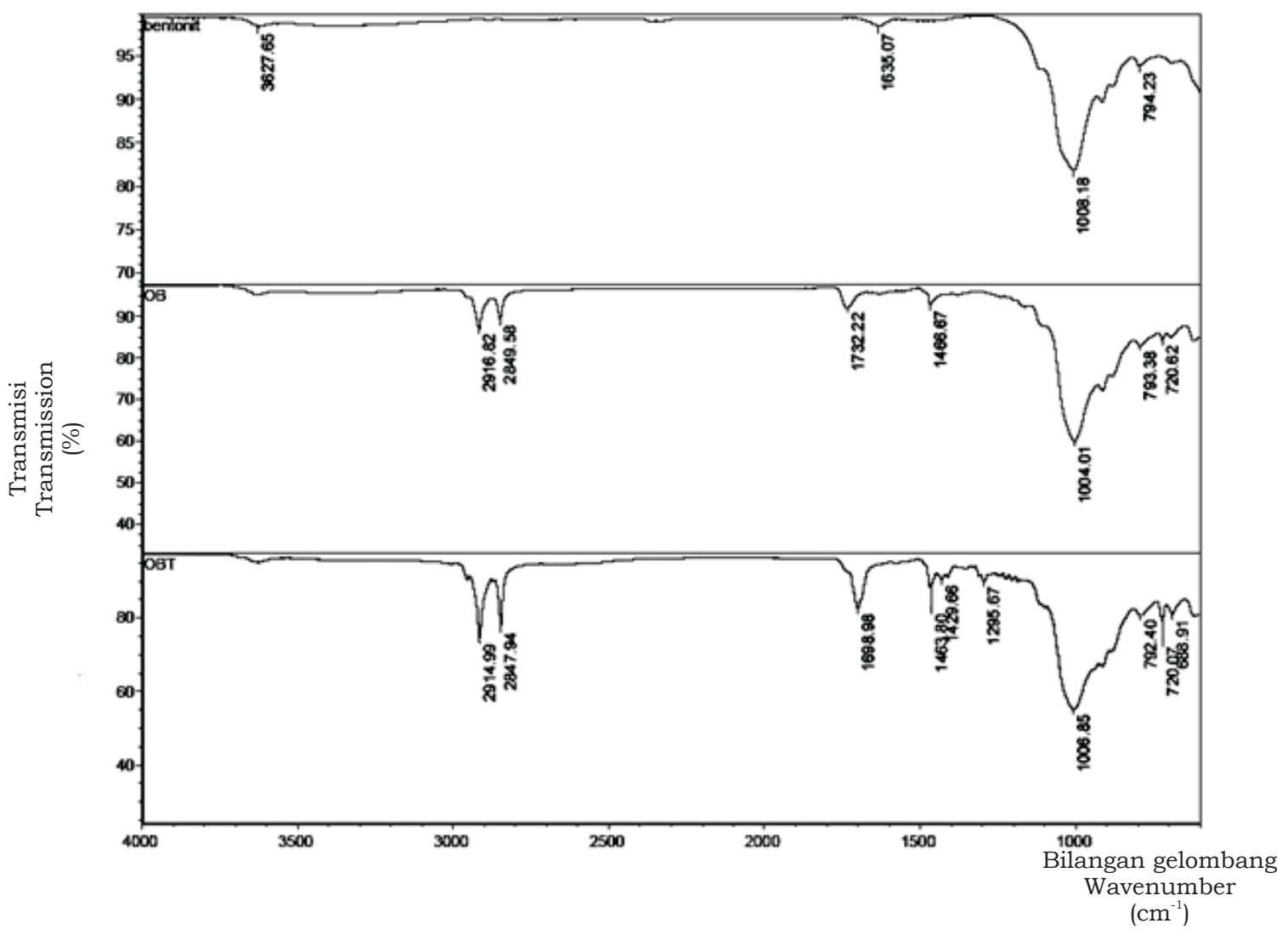

Gambar 2. Spektrum ATR-IR bentonit, OB, dan OBT

Figure 2. ATR-IR spectrums of bentonite, $O B$, and $O B T$ 


\section{Karakteristik Pematangan Kompon Campuran NR-BR}

Karakteristik pematangan yang terdiri dari torsi maksimum $\left(\mathrm{S}_{\max }\right)$, torsi minimum $\left(\mathrm{S}_{\min }\right)$, $\mathrm{S}\left(\mathrm{S}_{\max }-\mathrm{S}_{\min }\right)$, waktu pematangan optimum $\left(\mathrm{t}_{90}\right)$, dan waktu scorch $\left(\mathrm{ts}_{2}\right)$ dikompilasi dalam Tabel 2. Torsi maksimum dari kompon campuran NR-BR dengan bahan pengisi OBT lebih kecil bila dibandingkan dengan bahan pengisi $\mathrm{CB}$ dan $\mathrm{Si}$. Namun, $t_{90}$ dan $t_{2}$ relatif sama. Torsi minimum OBT dan $\mathrm{CB}$ juga lebih kecil dibanding dengan kompon NR-BR yang mengandung Si. Hal ini dikarenakan di dalam OBT mengandung sisa asam stearat yang dapat berfungsi sebagai pemlastis dari karet. Sisa asam stearat tersebut mengalami rekristalisasi pada saat proses pendinginan (Fathurrohman et al., 2013).

Tabel 2. Karakteristik pematangan kompon NR-BR dengan bahan pengisi OBT, CB dan $\mathrm{Si}$ Table 2. Curing characteristic of NR-BR compounds filled $O B T, C B$ and Si

\begin{tabular}{cccccc}
\hline $\begin{array}{c}\text { Sampel kompon } \\
\text { Compounds }\end{array}$ & $\begin{array}{c}\mathrm{S}_{\max } \\
(\mathrm{kg}-\mathrm{cm})\end{array}$ & $\begin{array}{c}\mathrm{S}_{\min } \\
(\mathrm{kg}-\mathrm{cm})\end{array}$ & $\begin{array}{c}\Delta \mathrm{S} \\
(\mathrm{kg}-\mathrm{cm})\end{array}$ & $\begin{array}{c}\mathrm{t}_{90} \\
(\text { menit })\end{array}$ & $\begin{array}{c}\mathrm{ts}_{2} \\
(\mathrm{menit})\end{array}$ \\
\hline OBT & 7,18 & 0,30 & 6,88 & 3,47 & 1,05 \\
$\mathrm{CB}$ & 9,24 & 0,29 & 8,95 & 3,26 & 1,13 \\
$\mathrm{Si}$ & 8,33 & 0,53 & 7,80 & 3,29 & 1,09 \\
\hline
\end{tabular}

Delta torsi (S) dapat diindikasikan secara tidak langsung sebagai pembentukan jaringan dalam sistem ikatan silang (Jovanovic et al., 2009). Kompon yang mengandung OBT memiliki $\mathrm{S}$ yang lebih kecil dibanding kompon 1 a innya, hal ini mengindikasikan derajat ikatan silang karena adanya bahan pengisi OBT lebih kecil dibanding kompon NR-BR yang mengandung CB dan Si. Derajat ikatan silang lebih besar menunjukkan peningkatan modulus, kekerasan dan menurunkan perpanjangan putus.

Indeks laju pematangan (CRI) mengindikasikan laju reaksi vulkanisasi yang dihitung dengan persamaan berikut:

$$
\mathrm{CRI}=\frac{100}{\mathrm{t}_{90}-\mathrm{ts}_{2}}
$$

Indeks laju pematangan disajikan pada Gambar 3. Pada Gambar 3 terlihat bahwa laju indeks pematangan kompon NR-BR dengan bahan pengisi OBT lebih kecil dibanding kompon NR-BR dengan bahan pengisi CB dan Si atau kecepatan pematangan kompon NR-BR yang mengandung OBT lebih lambat. Hasil ini berbeda dengan hasil penelitian yang dilakukan oleh Teh et al (2003), organobentonit mengandung grup amina yang dapat berfungsi sebagai bahan pencepat pada sistem vulkanisasi belerang yang akan meningkatkan laju indeks pematangan. Hal ini dimungkinkan karena adanya asam stearat sisa yang tidak bereaksi dengan organobentonit menyebabkan terhambatnya vulkanisasi dan zinc stearat dapat menghambat aktivitas dari $\mathrm{ZnO}$ (Jeon et al., 1999).

\section{Sifat Mekanik Vulkanisat Campuran NR-BR}

Sifat mekanik vulkanisat campuran NR-BR dengan bahan pengisi organobentonit terekspansi, karbon hitam dan silika disajikan pada Tabel 3. Kuat tarik vulkanisat dengan bahan pengisi OBT sedikit lebih besar bila dibandingkan dengan kuat tarik vulkanisat dengan bahan pengisi $\mathrm{CB}$, namun lebih rendah dibandingkan dengan vulkanisat dengan bahan pengisi Si. Hal ini mengindikasikan bahwa organobentonit terekspansi dapat menjadi bahan pengisi yang 


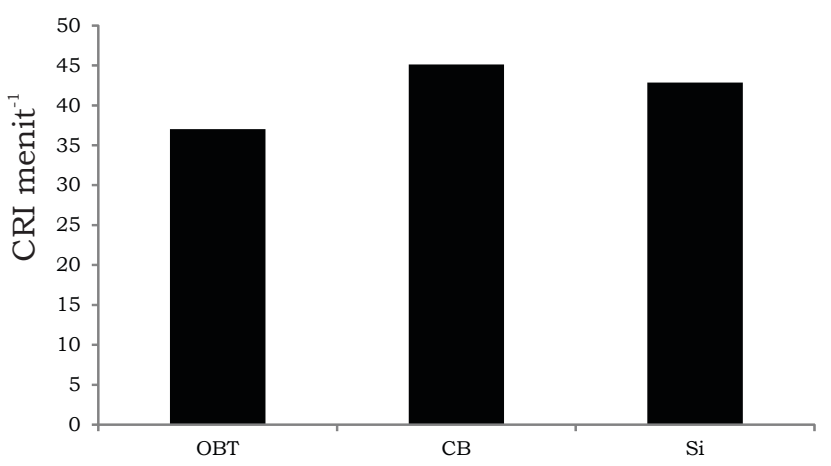

Gambar 3. Indeksi laju pematangan (CRI) kompon NR-BR dengan bahan pengisi OBT, CB dan Si. Figure 3. Curing rate index of NR-BR compound filled OBT, CB and Si.

bersifat menguatkan. Sifat penguatan tersebut dimungkinkan karena terjadinya interkalasi atau eksfoliasi dari OBT di dalam matrik campuran NR$\mathrm{BR}$ dan interaksi yang kuat antara permukaan lempung dengan matrik karet (Carli et al., 2011). Modulus 100\% dan modulus $300 \%$ vulkanisat dengan bahan pengisi OBT lebih besar dibandingkan dengan vulkanisat dengan bahan pengisi Si, namun sedikit lebih rendah dibandingkan dengan vulkanisat campuran NR-BR dengan bahan pengisi CB. Hasil ini sejalan dengan hasil perbedaan torsi pada rheometer yang mengindikasikan derajat ikatan silang dari vulkanisat NR$\mathrm{BR}$.

Perpanjangan putus vulkanisat campuran NR-BR dengan bahan pengisi
OBT sedikit lebih rendah dibandingkan dengan vulkanisat dengan bahan pengisi Si. Biasanya tingginya nilai kuat tarik akan mengakibatkan penurunan nilai perpanjangan putus (Madhusoodanan dan Varghese, 2006), namun pada vulkanisat dengan bahan pengisi OBT dan Si menunjukkan bahwa tingginya kuat tarik tidak mengakibatkan penurunan dari perpanjangan putus. Hal ini dimungkinkan karena lapisan silikat dan silika memiliki sifat penguatan sepanjang arah tarikan, yang akan berkontribusi terhadap peningkatan kuat tarik dan perpanjangan putus (Madhusoodanan dan Varghese, 2006). Sifat penguatan dari bahan pengisi dapat ditunjukkan dengan meningkatnya sifat kekuatan sobek dan ketahanan kikis. Kekuatan sobek dan

Tabel 3. Sifat mekanik vulkanisat NR-BR dengan bahan pengisi OBT, CB dan $\mathrm{Si}$ Table 3. Mechanical properties of NR-BR vulcanizates filled OBT, CB and Si

\begin{tabular}{|c|c|c|c|}
\hline $\begin{array}{l}\text { Parameter } \\
\text { Parameters }\end{array}$ & OBT & $\mathrm{CB}$ & $\mathrm{Si}$ \\
\hline Kuat tarik $\left(\mathrm{N} / \mathrm{mm}^{2}\right)$ & 12,57 & 12,09 & 15,41 \\
\hline Tensile Strenght & & & \\
\hline Modulus $100 \%\left(\mathrm{~N} / \mathrm{mm}^{2}\right)$ & 1,44 & 1,60 & 1,09 \\
\hline Modulus $300 \%\left(\mathrm{~N} / \mathrm{mm}^{2}\right)$ & 3,63 & 4,79 & 3,66 \\
\hline Perpanjangan putus (\%) & 530 & 480 & 610 \\
\hline Elongation at breaks & & & \\
\hline Kekuatan sobek $\left(\mathrm{N} / \mathrm{mm}^{2}\right)$ & 1,86 & 1,61 & 1,95 \\
\hline Tear Strenght & & & \\
\hline Ketahanan kikis $\left(\mathrm{mm}^{3}\right)$ & 148,91 & 270,46 & 184,71 \\
\hline Abrasion Resistance & & & \\
\hline $\begin{array}{l}\text { Kalor timbul } \\
\text { Heat Built Up }\end{array}$ & & & \\
\hline $\begin{array}{l}\text { - Perubahan suhu }(\mathfrak{C}) \\
\text { Temperature Changes }\end{array}$ & 6,50 & 6,50 & 4,60 \\
\hline $\begin{array}{l}\text { - Perubahan kekerasan (\%) } \\
\text { Hardness Changes }\end{array}$ & 1,23 & 0,62 & 0,7 \\
\hline
\end{tabular}


ketahanan kikis vulkanisat dengan bahan pengisi OBT dan Si lebih baik dibandingkan dengan vulkanisat dengan bahan pengisi CB. Hal ini disebabkan karena adanya interkalasi/eksfoliasi dari OBT sehingga meningkatkan luas permukaan dari OBT dan adanya peningkatan interaksi antara lapisan OBT dan karet (Madhusoodanan dan Varghese, 2006). Meningkatnya interaksi disebabkan adanya coupling agent yang dapat meningkatkan interaksi antara polimer dengan OBT dan Si (Ge dan Jia, 2010). Kekerasan dari ketiga bahan pengisi sedikit berbeda. Kekerasan kompon NR$\mathrm{BR}$ dengan bahan pengisi $\mathrm{CB}$ sedikit lebih besar. Hasil ini sama dengan nilai S pada karakteristik pematangan, mengindikasikan derajat ikatan silang kompon campuran NR-BR.

Nilai kalor timbul (heat build-up) dari vulkanisat campuran NR-BR dengan bahan pengisi OBT, CB dan $\mathrm{Si}$ yang diuji dengan mempelajari perubahan suhu dan perubahan kekerasan dari vulkanisat dengan bahan pengisi OBT, CB dan Si terlihat bahwa perubahan suhu dari vulkanisat NR-BR dengan bahan pengisi OBT dan $\mathrm{CB}$ lebih besar dibandingkan dengan vulkanisat dengan bahan pengisi Si. Selama pengujian kalor timbul, perubahan kekerasan dari vulkanisat dengan bahan pengisi OBT lebih besar dibandingkan dengan vulkanisat dengan bahan pengisi CB dan $\mathrm{Si}$.

\section{KESIMPULAN DAN SARAN}

Karakteristik pematangan dari kompon campuran NR-BR dengan bahan pengisi OBT menghasilkan torsi maksimum yang lebih kecil dibandingkan dengan bahan pengisi $\mathrm{CB}$ dan Si. Namun, $S$, $t_{90}$ dan $\mathrm{ts}_{2}$ relatif sama. Hal ini dipengaruhi oleh adanya asam stearat yang dapat berfungsi sebagai pemlastis. Sifat mekanik dari vulkanisat campuran NR-BR dengan bahan pengisi organobentonit terekspansi lebih baik dibandingkan dengan bahan pengisi $\mathrm{CB}$ terutama untuk sifat kuat tarik, perpanjangan putus, kekuatan sobek, dan ketahan kikis. Berdasarkan hasil sifat mekanik, maka dapat disimpulkan bahwa organobentonit terekspansi dapat digunakan sebagai bahan pengisi yang bersifat menguatkan pada vulkanisat campuran NR-BR.

Untuk tahap penelitian selanjutnya disarankan dapat dibandingkan antara sifat mekanik campuran NR-BR dengan bahan pengisi OBT dan bahan pengisi organobentonit yang memiliki basal spasi yang sama, serta dengan mencampurkan antara carbon black atau silika dengan organobentonit sebagai bahan pengisi di dalam kompon karet.

\section{DAFTAR PUSTAKA}

Alexandre, M. and P. Dubois. 2000. Polymer-Layered Silicate Nanocomposites: Preparation, Properties, and Uses of a New Class of Materials. Material Science and Engineering 28: 1-63.

Carli, L. N., C. R. Roncato, A. Zanchet, R. S. Mauler, M. Giovanela, R.N. Brandalise, and J. S. Crespo. 2011. Characterization of Natural Rubber Nanocomposites Filled with Organoclay as a Substitute for Silica Obtained by the Conventional Two-Roll Mill Method. Applied Clay Science 52: 56-61.

Das, A., F. R. Costa, U. Wagenknecht, and G. Heinrich. 2008 . Nanocomposites Based on Chloroprene Rubber: Effect of Chemical Nature and Organic Modification of Nanoclay on the Vulcanizate Properties. European Polymer Journal 44 (11): 34563465.

Datta, S. 2004. Special-Purpose Elastomers. In Brendan Rodgers. Rubber Compounding: Chemistry and Applications. Marcel Dekker Inc, New York: 105-132.

Fathurrohman, M. I., B. Soegijono, and E. Budianto. 2013. The Effect of Stearic Acid on Expanded Organoclay and Rheometric Properties of Natural Rubber/Expanded Organoclay Nanocomposites. Journal of Materials Science and Engineering B3 (9): 575-581. 
Ge, M. and D. Jia. 2010. Influence of Coupling Agent on the Properties and Structures of Poly(Vinyl Chloride)/Clay Nanocomposites. Journal of Thermoplastic Composite Materials 23: 855-869.

Jeon, G. S., M. H. Han, and G. Seo. 1999. The Adhesion Properties of Stearic Acid-loaded Rubber Compounds to Brass-Plated Steel Cord. Korean Journal Chemical Engineering 16 (4): 434-440.

Jovanovic, V., B. J. Simendic, S. S. Jovanovic, G. Moarkovic, and M. M. Concovic. 2009. The Influence of Carbon Black on Curing Kinetics and Thermal Aging of AcrilonitrileButadiene Rubber. Chemical Industry \& Chemical Engineering 15 (4): 283-289.

Le Pluart, L., J. Duchet, H. Sautereau, and J. F. Gerard. 2002. Surface Modifications of Montmorillonite for Tailored Interfaces in Nanocomposites. The Journal of Adhesion 78: 645-662.

Lopez-Manchado, M. A., B. Herrero, and M. Arroyo. 2003. Preparation and Characterization of Organoclay Nanocomposites Based on Natural Rubber. Polymer International 52: 1070-1077.

Ma, Y., L. Qi-Fang, Z. Li-Qun, and W. You-Ping. 2007. Role of Stearic Acid in Reparing EPDM/Clay Nanocomposites by Melt Compounding. Polymer Journal 39 (1): 1-7.

Ma, Y., W. You-Ping, Z. Li-Qun, and L. Qi-Fang. 2008. The Role of Rubber Characteristics in Preparing Rubber/Clay Nanocomposites by Melt Compounding. Journal of Applied Polymer Science 109: 19251934.

Madhusoodanan, K.N., and S. Varghese. 2006 . Tehcnological and Processing of Natural Rubber Layered Silicate-Nanocomposites by Melt Intercalation Process. Journal of Applied Polymer Science 102: 2537-2543.
Ramadhan, A., B. Soegijono, dan M.I. Fathurrohman. 2014. Pengaruh Organobentonit dan Asam Stearat Terhadap Karakteristik Pematangan dan Sifat Mekanik Vulkanisat Karet Alam. Jurnal Penelitian Karet 32 (1): 45-55.

Sadhu, S. and A.K. Bhowmick. 2004. Preparation and Properties of Styrene-Butadiene Rubber Based Nanocomposites: the Influence of the Structural and Processing Parameters. Journal of Applied Polymer Science 92: 698-709.

Shan, C., Z. Gu, L. Wang, P. Li, G. Song, $Z$. Gao, and X. Yang. 2011. Preparation, Characteriation, and A p p 1 i c a t i o $n$ o f N R / S B R / O r g a n o c l a y Nanocomposites in the Tire Industry. Journal of Applied PolymerScience 119: 1185-1194.

Teh, P. I., Z. A. Mohd Ishak, U. S. Ishiaku, and J. Karger-Kocsis. 2003. Cure Characteristic and Mechanical Properties of Natural $\mathrm{R} u$ b b e r / O r g a n o c 1 a y Nanocomposites. Jurnal Teknologi 39 (A): 1-10.

Wan, C., W. Dong, Yinxi Zhang, and Yong Zhang. 2008. Intercalation Process and Rubber-Filler Interactions of Polybutadiene Rubber/Organoclay Nanocomposites. Journal of Applied Polymer Science 107: 650657.

Yong-Lai, L., L. Yu-Rong, W. You-Ping, and Z. Li-Qun. 2006. Effects of Heat and Pressure on Microstructure of IsobutyleneIsoprene Rubber (IIR)/Clay Nanocomposites. Macromolecular Materials and Engineering 291: 27 36. 